\title{
EDITORIAL
}

\section{In This Issue: Trends, Prescribing, Deprescribing}

\author{
Kurt C. Stange, Editor
}

Ann Fam Med 2017;15:302-303. https://doi.org/10.1370/afm.2118.

$\mathrm{T}$ This issue begins by showing trends in health service use and goes on to unpack myriad factors affecting health care delivery, its appropriateness, and the ability of primary care clinicians to serve their role in integrating and personalizing care.

An assessment of changes in the ecology of medical care over the last 15 years shows large increases in every category of health care spending, with the exception of primary care physician and home health. The largest absolute increases are in prescribed medications, specialty physician and emergency department visits, and inpatient hospitalization. ${ }^{1}$ It is hard not to wonder if increasing resources on primary care and home care services would help reduce spending on drugs and emergency departments, and hospital care. In an accompanying editorial, Karen DeSalvo emphasizes the importance of attending to social needs of patients and communities in order to improve care, lower costs, and reverse health disparities. ${ }^{2}$

In contrast, and in partial explanation of the trends toward greater prescribing, Wallis and colleagues identify barriers and enablers to deprescribing. Purposively sampled and deeply interviewed primary care clinicians describe "'swimming against the tide' of patient expectations, the medical culture of prescribing, and organizational constraints" including time pressures, fragmentation of care, and poor information flows between multiple prescribers. ${ }^{3}$ The opportunities they identify to support deprescribing are worthy of policy and practice system support.

A group of articles explores the role of primary care in treating opioid use disorder through medication, listening, and caring. The challenges to prescribing buprenorphine for treatment of opioid addition in rural areas are exposed by Andrilla et al ${ }_{1}^{4}$ while a study by Dupouy et al reveals that being out of treatment increases the risk of death nearly 30 -fold for patients on buprenorphine. ${ }^{5}$ An essay by Gastala puts a face on this crisis by sharing the experiences of a new family physician in a rural town with liberal opioid prescribing and rampant opioid addiction. ${ }^{6}$ In a PointCounterpoint, Loxterkamp and Hill make cases for and against the proposition that medication-assisted treatment should be part of every family physician's prac- tice. ${ }^{7.8}$ An editorial by Saitz argues that primary care is the place to treat opioid use disorder and that the time for such treatment is now. ${ }^{9}$

It is hard to read these studies and not think about upstream causes of an increasingly fragmented and depersonalized society and health care system that make the quick fix of prescriptions so rampant and accepted. In the short term, it is easier to mask than to deal with the pain of a society that amplifies division over commonality and a system that values care commodities over caring relationships.

Trends in turnover among physicians are documented by McGrail et al, with more than double the rate of turnover among younger vs older physicians. There is greater mobility in counties with no hospital, smaller population size, and lower physician supply. Female physicians of urban origin are more likely to leave rural practice. ${ }^{10}$

A "secret shopper method" allows Williams and colleagues to identify challenges to accessing behavioral health care. The rate at which an insured new patient can get an appointment in the Denver area differs widely-from $10 \%$ to $59 \%$ - varying with type of insurance. ${ }^{11}$

A proposal to overcome the dangers of discontinuity and fragmentation of care when patients are hospitalized is suggested by Doohan and DeVoe. They propose that every hospital needs a Chief Primary Care Medical Officer who is expert in practice across the spectrum of care. ${ }^{12}$

Recent cervical cancer screening guideline changes in Ontario are associated with reduced chlamydia testing and reduced reported chlamydia incidence for young women. Chlamydia incidence remains the same for males, despite increased chlamydia testing. ${ }^{13}$

A factorial cluster randomized controlled trial in 5 European countries tests the effect of training and support, financial reimbursement, and electronic brief advice on the proportion of patients given an intervention for heavy drinking in general practices. The study finds that training and support has a modest effect at 9 months. ${ }^{14}$

A clinical decision rule for acute rhinosinusitis and acute bacterial rhinosinusitis developed by Ebell and 
Hansen using classification and regression tree analysis finds reasonable performance that begs for prospective validation and assessment of effect on clinical outcomes. ${ }^{15}$

Contrasting essays address the personal aspects of physician burnout and its prevention. Lathrop explores the relationship of burnout to unacknowledged loss and grief. ${ }^{16}$ Shaughnessy and colleagues uncover the benefits of written reflection to develop an inner life that fosters meaning amidst challenge. ${ }^{17}$

Finally, this issue continues the new Annals feature on Innovations in Primary Care. ${ }^{18}$ The innovations in this issue explore the role of technology at the patient, practice, system, and national levels. An online survey helps clinicians gauge and address patients' confidence in their ability to manage their health, ${ }^{19}$ while the development of telemedicine in Brazil increases patients' access to care. ${ }^{20}$

We welcome you to join the online discussion of Annals articles at http://www.AnnFamMed.org.

\section{References}

1. Johansen ME. Comparing medical ecology, utilization, and expenditures between 1996-1997 and 2011-2012. Ann Fam Med. 2017; 15(4):313-321.

2. DeSalvo KB, Harris A. Bending the trends. Ann Fam Med. 2017; 15(4):304-306.

3. Wallis KA, Andrews A, Henderson M. Swimming against the tide: primary care physicians' views on deprescribing in everyday practice. Ann Fam Med. 2017;15(4):341-346.

4. Andrilla CHA, Coulthard C, Larson EH. Barriers rural physicians face prescribing buprenorphine for opioid use disorder. Ann Fam Med. 2017;15(4):359-362.

5. Dupouy J, Palmaro A, Fatséas M, et al. Mortality associated with time in and out of buprenorphine treatment in French office-based general practice: a 7-year cohort study. Ann Fam Med. 2017;15(4): 355-358.
6. Gastala N. Denial: the greatest barrier to the opioid epidemic. Ann Fam Med. 2017;15(4):372-374.

7. Loxterkamp D. Medication-assisted treatment should be part of every family physician's practice: Yes. Ann Fam Med. 2017;15(4): 309-310.

8. Hill RR. Medication-assisted treatment should be part of every family physician's practice: No. Ann Fam Med. 2017;15(4):311-312.

9. Saitz R, Daaleman TP. Now is the time to address substance use disorders in primary care. Ann Fam Med. 2017;15(4):306-308.

10. McGrail MR, Wingrove PM, Petterson SM, Bazemore AW. Mobility of US rural primary care physicians during 2000-2014. Ann Fam Med. 2017;15(4):322-328.

11. Williams MO, Gilroy JR, Chang TY, Seymour DJ. Challenges for insured patients in accessing behavioral health care. Ann Fam Med. 2017;15(4):363-365.

12. Doohan N, DeVoe J. The chief primary care medical officer: restoring continuity. Ann Fam Med. 2017;15(4):366-371.

13. Naimer MS, Kwong JC, Bhatia D, et al. The effect of changes in cervical cancer screening guidelines on chlamydia testing. Ann Fam Med. 2017;15(4):329-334

14. Anderson $P$, Coulton S, Kaner E, et al. Delivery of brief interventions for heavy drinking in primary health care: outcomes of the ODHIN 5-country cluster randomized trial. Ann Fam Med. 2017; 15(4):335-340.

15. Ebell MH, Hansen JG. Proposed clinical decision rules to diagnose acute rhinosinusitis among adults in primary care. Ann Fam Med. 2017;15(4):347-354.

16. Lathrop D. Disenfranchised grief and physician burnout. Ann Fam Med. 2017;15(4):375-378.

17. Shaughnessy AF, Vicini A, Duggan AP. Cultivating the inner life of a physician through written reflection. Ann Fam Med. 2017;15(4): 379-381.

18. Stange KC. Innovations in primary care and at the Annals. Ann Fam Med. 2017;15(3):202. http://www.AnnFamMed.org/content/15/3/202. full.

19. Ho L, Antonucci J. Using patient-entered data to supercharge selfmanagement. Ann Fam Med. 2017;15(4):382.

20. Goncalves MR, Umpierre RN, D'Avila OP, et al. Expanding primary care access: a telehealth success story. Ann Fam Med. 2017; 15(4):383. 